\title{
Middle to Late Holocene vegetation shifts in the NW Transylvanian lowlands (Romania)
}

\author{
Roxana GRINDEAN ${ }^{*}$, Ioan TANȚĂU ${ }^{1,2}$, Sorina FĂRCAŞ², Andrei PANAIT ${ }^{1}$
}

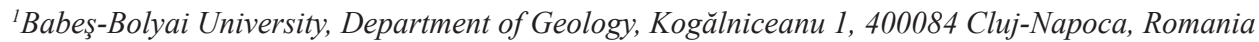 \\ ${ }_{2}^{2}$ Institute of Biological Research, Republicii 48, 400015 Cluj-Napoca, Romania
}

Received: July 2014; accepted November 2014

Available online 4 December 2014

DOI: http://dx.doi.org/10.5038/1937-8602.59.1.2

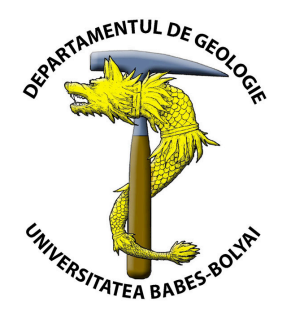

\begin{abstract}
The Iaz peat bog, located in northwestern Transylvania at $300 \mathrm{~m}$ a.s.l., was cored to study the Middle to Late Holocene vegetation shifts in the area. The pollen record is supported by seven ${ }^{14} \mathrm{C}$ datings. The base of the sequence starts in the Middle Holocene, when the outer woodlands were dominated by Corylus avellana together with other components of the Quercetum mixtum. The local establishment of Carpinus betulus occurred at 5700 cal. yr BP with maximum values at around $4900 \mathrm{cal}$. yr BP. At $4800 \mathrm{cal}$. yr BP, Fagus sylvatica became locally established and expanded, possibly as a result of moist climatic conditions and dominated the mesothermophilous woodlands from 4300 cal. yr BP onwards. During the periods of greater moisture, the deciduous forest was overgrown by the hygrophilous Alnus glutinosa belt. Indications of human activities in the area were recorded since 6300 cal. yr BP, when Cerealia and Secale pollen and other ruderal taxa start to appear regularly throughout the sequence. Although intense at times, the anthropogenic factor only played a major role in the vegetation changes during the last 635 years.
\end{abstract}

Keywords: vegetation shift, pollen, peat bog, forest belt, Holocene, lowland, Romania.

\section{INTRODUCTION}

The Apuseni Mountains host over half of the oligotrophic peat bogs in Romania (Pop, 1960). Modern studies that include ${ }^{14} \mathrm{C}$ datings have been conducted on peat sequences located at mid and high altitudes in these mountains (Bodnariuc et al., 2002; Fărcaş et al., 2005; Feurdean and Willis, 2008). The palaeoecological results derived from these multi-proxy studies suggest that the forests dominated by Picea abies, Betula and Corylus between 10200 and 6500 cal. yr BP are associated with a cool climate. Furthermore, the expansion of Carpinus in the area, between ca. 6500 cal. yr BP (Fărcaş et al., 2005) and 5500 cal. yr BP (Feurdean and Willis, 2008), probably takes place at a transition to a warmer climate, with dry summers. In accordance with these results, Fagus sylvatica starts expanding in the Apuseni Mountains ca. 4500 years ago. This happens mainly at the expense of Quercus, Carpinus and Ulmus. Taking in consideration that Fagus sylvatica is a tree taxon sensitive to the humidity factor, its expansion and dominance in the area, as well as those of Abies, during the last 4000 years, may indicate a climate with cool and wet summers, and mild winters (Fărcaş et al., 2007).

The present palynological study was conducted on a $5.40 \mathrm{~m}$ long peat sequence from the foothill of the Plopiş Mountains (Apuseni Mountains, NW Romania). Our main goals were: i) to determine the vegetation dynamics and composition within the peat bog, in accordance with the changes in climate and ecological conditions; ii) to assess the impact of anthropogenic activity on the local and regional vegetation in this understudied region, during the Middle to Late Holocene. For a better overview of these vegetation shifts, we have compared our results with pollen and microcharcoal records from other sites in NW Romania: Preluca Ţiganului
(Feurdean, 2005; Feurdean et al., 2008), Steregoiu (Björkman et al., 2003; Feurdean et al., 2008), Turbuţa (Feurdean et al., 2007), Molhașu Mare (Feurdean and Willis, 2008), Ic Ponor (Bodnariuc et al., 2002; Jalut et al., 2003), Căpăţâna (Fărcaş et al., 2005) and Lake Ştiucii (Feurdean et al., 2013).

\section{STUDY AREA}

The peat bog from Iaz $\left(47^{\circ} 06^{\prime} 30^{\prime \prime} \mathrm{N}, 22^{\circ} 39^{\prime} 40^{\prime \prime} \mathrm{E}\right)$ is situated in the central part of the Natural Reservation "Mlaştina de la Iaz", in the Plopiş Mountains, NW Romania, at an altitude of ca. $300 \mathrm{~m}$ a.s.l. (Fig. 1). The surface of the peat bog is of about 0.35 ha with a recorded depth of $5.10 \mathrm{~m}$ (Munteanu and Raus, 1984). The region is characterized by a temperate continental climate with annual precipitation above $700 \mathrm{~mm}$ and a mean annual temperature of $8^{\circ} \mathrm{C}$ (Institute of Biological Research, 2012).

The reservation covers an area of 10 ha and is delimited to the north and northeast by woodlands composed mainly of Fagus sylvatica and Quercus petraea, to the east by an abandoned orchard, and at the south and west by meadows and an access road. The previous investigations in the area have suggested that the peat bog started to develop about $8000 \mathrm{yr} \mathrm{BP}$, offering a high resolution for the period dominated by Fagus sylvatica forests (Coldea, 1971).

The swamp within the reservation is surrounded by two dense forest belts which provide protection and preservation of the meso-oligotrophic vegetation: an inner forest belt dominated by Alnus glutinosa and the outer forest belt consisting mainly of Fagus sylvatica, Quercus petraea and Corylus avellana (Fig. 2). Nowadays, the peat bog covers one third of the reservation and the swamp within hosts a protected phytocoenosis with 
Carex echinata, Sphagnum amblyphyllum, S. magellanicum, S. recurvum, Polytrichum strictum, Eriophorum angustifolium,
Calamagrostis canescens and Drosera rotundifolia (Institute of Biological Research, 2012).

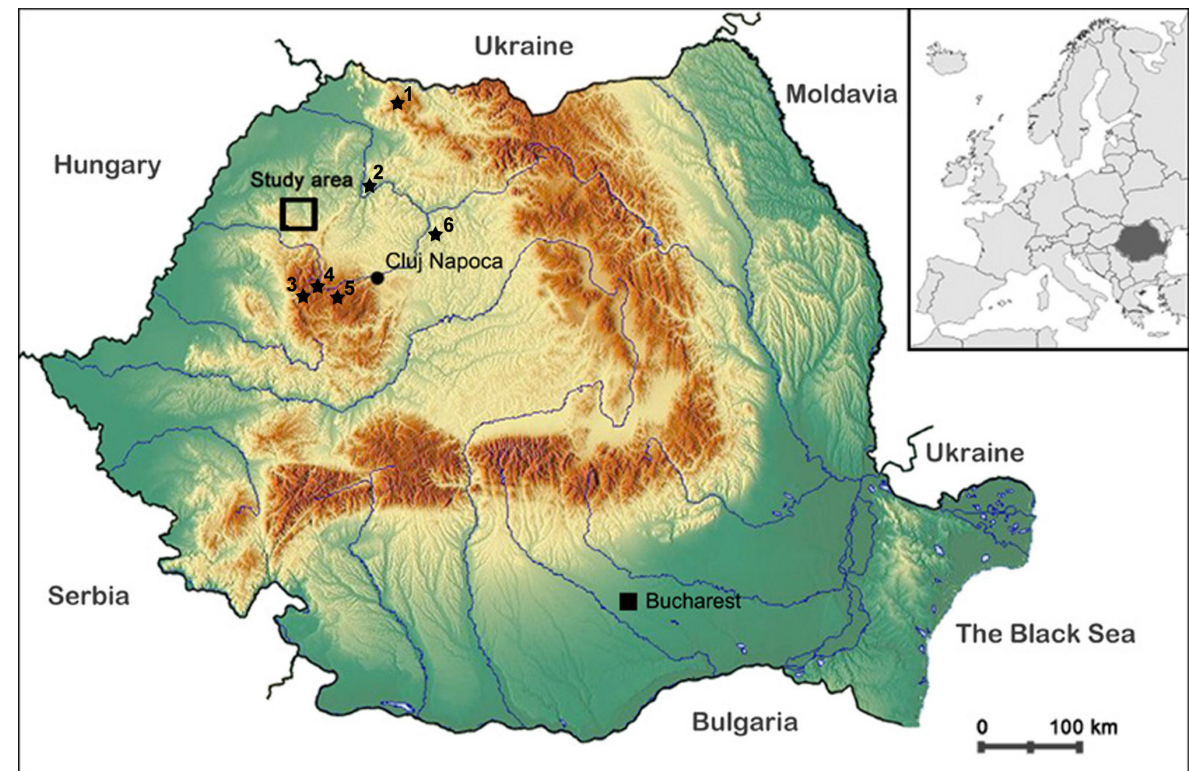

Fig. 1. Location map of the study area in the Apuseni Mountains and sites mentioned in the text: 1) Preluca Tiganului (Feurdean, 2005; Feurdean et al., 2008), Steregoiu (Björkman et al., 2003; Feurdean et al., 2008); 2) Turbuța (Feurdean et al., 2007); 3) Molhașu Mare (Feurdean and Willis, 2008); 4) Ic Ponor (Bodnariuc et al., 2002, Jalut et al., 2003); 5) Căpăţâna (Fărcaş et al., 2005); 6 - Lake Ştiucii (Feurdean et al., 2013).

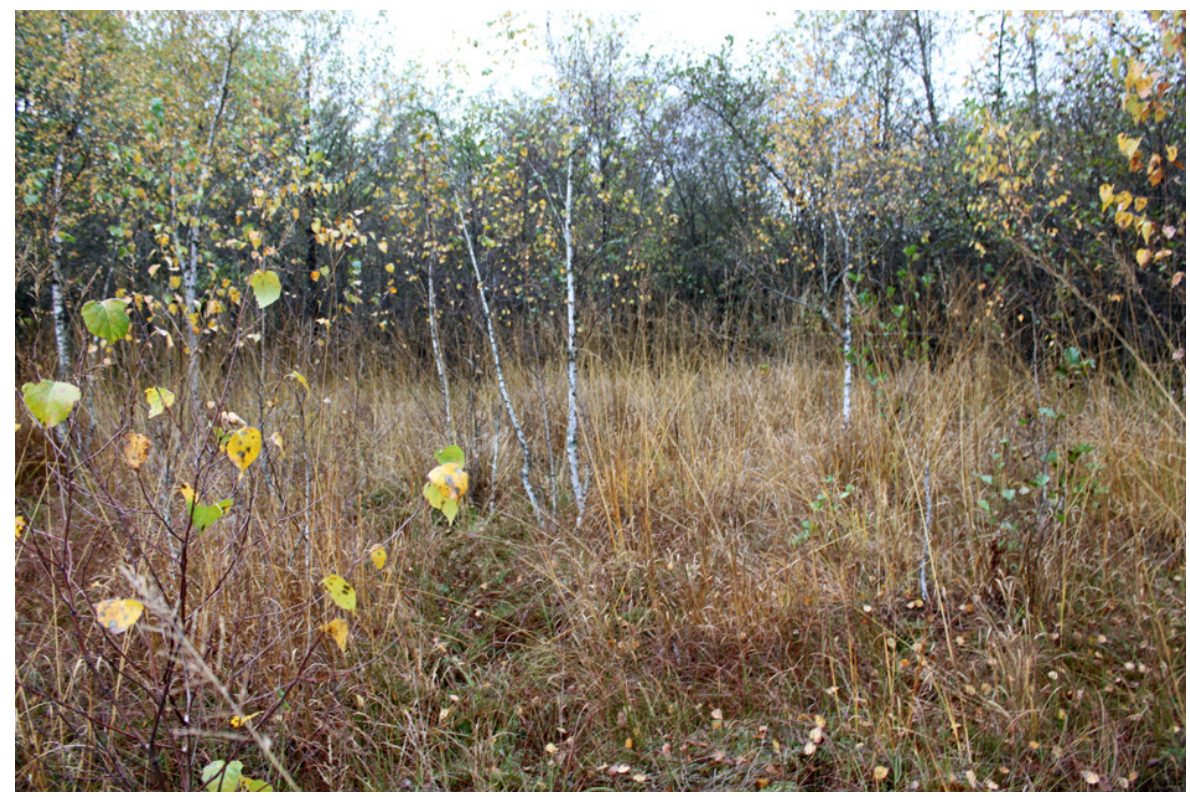

Fig. 2. Present vegetation in the Iaz peat bog and the coring location.

\section{MATERIALS AND METHODS}

A single core was taken with a hand-operated "Russian sampler", $6 \mathrm{~cm}$ in diameter and with a chamber length of $60 \mathrm{~cm}$. The core taken near the center of the peat bog reached the basal sediments at $5.40 \mathrm{~m}$. The sediments were preliminary described in the field and thereafter placed in half PVC tubes and wrapped in plastic films. Before laboratory sub-sampling, all cores were carefully cleaned and described again.

The cores were regularly sub-sampled $\left(1 \mathrm{~cm}^{3}\right)$ at $5 \mathrm{~cm}$ intervals for pollen analysis. The sample preparation followed the standard procedure with acetolysis in the case of peat and gyttja samples, and flotation with $\mathrm{ZnCl}_{2}$ for clayey samples. The residue was used to prepare thin sections and these were scored for pollen. A minimum of 350 terrestrial pollen grains were counted for each sub-sample. Pollen keys and illustrations from Reille $(1995,1998,1999)$ were used for pollen identification. The nomenclature for vascular plants follows Flora Europaea (Tutin et al., 1964-1980).

The GpalWin software (Goeury, 1997) was used for preparing the pollen diagram. The frequencies for each taxon were calculated as percentages of the total pollen sum (arboreal 
pollen - AP and non-arboreal pollen - NAP) which excluded aquatic taxa and spores. Due to its high representation in the pollen spectra, Alnus pollen was also excluded from the terrestrial pollen sum.

Seven samples of bulk peat were dated by the AMS method at the Radiocarbon Laboratory in Poznań (Poland). Using the INTCAL13 data set of Reimer et al. (2013), the AMS ${ }^{14} \mathrm{C}$ measurements were converted into calendar years BP via the Clam software (Blaauw, 2010).

\section{RESULTS}

\section{Chronology}

Uncalibrated and calibrated ${ }^{14} \mathrm{C}$ ages are given in Table 1. Due to poor pollen preservation in the bottom clayey part of the sequence and a possible hiatus at around $5.20 \mathrm{~m}$, we have ruled out the first radiocarbon date of $8380 \pm 50 \mathrm{BP}$. Therefore we have used known pollen stratigraphic markers from nearby sites to assign the beginning of the

Table 1. $A M S{ }^{14} \mathrm{C}$ measurements and calibrated range age for the Iaz sequence.

\begin{tabular}{ccccc}
\hline $\begin{array}{c}\text { Depth } \\
(\mathrm{cm})\end{array}$ & $\begin{array}{c}\text { Laboratory } \\
\text { number }\end{array}$ & ${ }^{14}$ C yr BP & $\begin{array}{c}\text { Cal. yr BP } \\
(2 \sigma)\end{array}$ & $\begin{array}{c}\text { Data use to } \\
\text { reconstruct } \\
\text { chronology } \\
\text { (cal. yr BP) }\end{array}$ \\
\hline $12-14$ & Iaz I13 & $121.04 \pm 0.36$ & $44-153$ & 75 \\
$132-134$ & Iaz I133 & $1150 \pm 30$ & $1004-1173$ & 1078 \\
$212-214$ & Iaz I213 & $1805 \pm 30$ & $1673-1861$ & 1776 \\
$282-284$ & Iaz I283 & $2520 \pm 35$ & $2064-2569$ & 2343 \\
$342-344$ & Iaz I343 & $2395 \pm 35$ & $2530-3145$ & 2724 \\
$442-444$ & Iaz I443 & $4090 \pm 35$ & $4627-4670$ & 4647 \\
$532-534$ & Iaz I533 & $8380 \pm 50$ & - & Not used \\
\hline
\end{tabular}

peat sedimentation in our sequence to a given age. Thus, our pollen record from the Iaz peat sequence starts at about 7000 cal. yr BP. Additional estimated ages for the expansion and maximum of Carpinus betulus and the establishment and expansion of Fagus sylvatica, were obtained by comparison with other sequences from the region (Björkman et al., 2003; Bodnariuc et al., 2002; Jalut et al., 2003; Feurdean, 2005; Feurdean et al., 2007, 2008, 2013; Feurdean and Willis, 2008).

The accumulation rate of sediments was calculated based on the age-depth model (Fig. 3), which was constructed using the midpoints of the $2 \sigma$ calibrated age ranges of the dates.

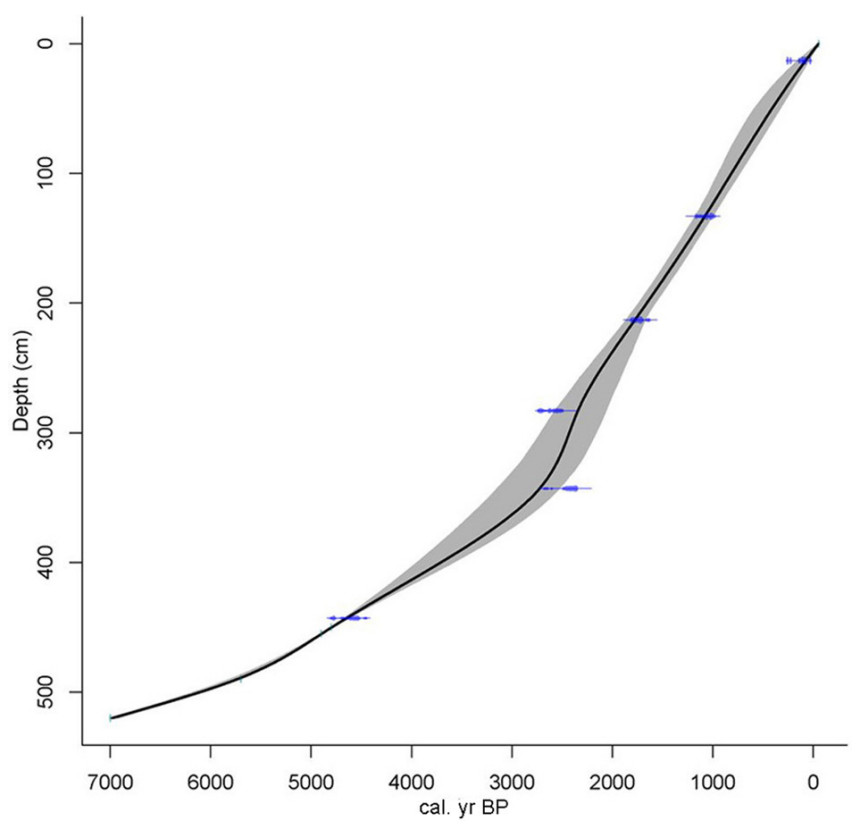

Fig. 3. An age-depth model for the Iaz sequence with the dating error bars (smoothing spline with 0.3 smooth; 1000 itinerations).

\section{Lithostratigraphy}

A simplified stratigraphy for the analyzed profile $(0-5.40 \mathrm{~m})$ is presented in Table 2 (see also lithology column in the pollen diagram, Fig. 4). The bottom $20 \mathrm{~cm}$ of the sequence consists of clayey gyttja followed by clayey peat between $5.20-4.20 \mathrm{~m}$. The remaining top $4.20 \mathrm{~m}$ of the sequence is composed of peat with various degrees of humidification and composition (Table 2). The topmost part of the sequence $(0-0.60 \mathrm{~m})$ consists of undecomposed peat.

\section{Pollen analysis}

A total of 109 pollen spectra were analyzed and 71 taxa were identified for the Iaz sequence. By comparing frequencies and dynamics of the main pollen taxa, 6 Local Pollen Assemblage Zones (LPAZ 1-6) were established in order to facilitate the description and interpretation of the pollen diagram regarding changes in vegetation (Fig. 4).

\section{LPAZ 1 (5.20 - $4.90 \mathrm{~m} ; 7000$ - $5700 \mathrm{cal}$. yr BP)}

In the first half of the zone, Corylus avellana values exceed $35 \%$ and other deciduous trees, such as Tilia, Quercus and Ulmus, reach values as high as $10-15 \%$. The herbaceous taxa are present with values of about $30 \%$ in the beginning of the sequence, only to have a sudden decrease shortly after.

The second half of the zone has several features: a) a sudden decline of Corylus avellana (pollen values drop from 50\% to $25 \%$ ), b) a decrease of the mesothermophilous taxa (Tilia, Quercus, Ulmus), c) an increase in pioneer tree taxa (Picea abies, Betula, Fraxinus) and d) an increase of the herbaceous taxa that reach the $30 \%$ limit once more in the same zone. Carpinus betulus starts to expand at the end of the zone, when scattered but regular pollen grains of Fagus sylvatica pollen are also observed.

\section{LPAZ 2 (4.90 - 4.35 m; 5700 - 4500 cal. yr BP)}

In this zone Corylus avellana pollen percentages become reduced to $15 \%$ and Carpinus betulus reaches its maximum 
Table 2. Simplified stratigraphic description and accumulation rates of the Iaz sequence.

\begin{tabular}{|c|c|c|}
\hline Depth (m) & Stratigraphic description & Accumulation rates $\left(\mathrm{cm} \mathrm{a}^{-1}\right)$ \\
\hline $0.00-0.25$ & Undecomposed Sphagnum peat & 0.10 \\
\hline $0.25-0.60$ & Sphagnum peat, fibrous, moderately humified, light brown & $0.10-0.12$ \\
\hline $0.60-0.80$ & $\begin{array}{l}\text { Sphagnum peat, fibrous, moderately humified, with vegetal } \\
\text { remains, dark brown }\end{array}$ & 0.12 \\
\hline $0.80-1.20$ & Carex-Sphagnum peat, moderately humified, fibrous, dark brown & 0.12 \\
\hline $1.20-1.90$ & Carex-Sphagnum peat, very humid, dark brown & $0.12-0.11$ \\
\hline $1.90-2.40$ & $\begin{array}{l}\text { Carex-Sphagnum peat, very humid, fibrous, with wood remains, } \\
\text { dark brown }\end{array}$ & 0.11 \\
\hline \multirow{2}{*}{$2.40-3.20$} & \multirow{2}{*}{$\begin{array}{l}\text { Carex-Sphagnum peat, moderately humified, with vegetal } \\
\text { remains, dark brown }\end{array}$} & $0.11-0.19(2.40-2.90 \mathrm{~m})$ \\
\hline & & $0.20-0.16(2.91-3.19 \mathrm{~m})$ \\
\hline \multirow{2}{*}{$3.20-3.60$} & \multirow{2}{*}{$\begin{array}{l}\text { Clayey Carex peat, moderately humified, with large wood } \\
\text { remains, dark brown }\end{array}$} & $0.16-0.10(3.20-3.38 \mathrm{~m})$ \\
\hline & & $0.09-0.06(3.39-3.59 \mathrm{~m})$ \\
\hline $3.60-4.20$ & Clayey Carex peat, very humid, with wood remains, dark brown & $0.06-0.04$ \\
\hline $4.20-5.20$ & $\begin{array}{l}\text { Clayey Carex peat, moderately humid, dark brown, distinct } \\
\text { lower boundary }\end{array}$ & $0.04-0.02$ \\
\hline$>5.20 \mathrm{~m}$ & Clayey gyttja & \\
\hline
\end{tabular}

of $50 \%$ at around 4900 cal. yr BP. The mesothermophilous taxa have slightly different dynamics during this period: Tilia decreases while Quercus and Ulmus maintain similar values to the ones from the previous zone. Regularly present throughout most of the zone, Fagus sylvatica expands starting with 4800 cal. yr BP. Picea abies and Pinus percentages often exceed the $1 \%$ limit. As the AP increases, values of herbs such as Poaceae, Artemisia and wetland herbs decline and ruderal taxa start to diversify. Noteworthy is the presence of single pollen grains of Arctium lappa and Plantago lanceolata and regular Cerealia pollen. Monolete spores values slightly increase and Sphagnum is also present.

\section{LPAZ 3 (4.35 - 2.90 m; 4500 - 2400 cal. yr BP)}

Corylus avellana percentages rarely exceed $10 \%$ and Tilia and Ulmus record an accentuated decline, whereas Quercus holds similar values to those of the previous zone. Fagus sylvatica and Carpinus betulus have the highest values in the beginning of the zone. Abies alba is also regularly present. The values of $F$. sylvatica and $C$. betulus tree taxa are outnumbered towards the middle of the zone by Alnus percentage values. Betula and Fraxinus values often alternate around 1\%. Vitis pollen percentages exceed $1 \%$ values by the middle of this zone. Wetland herbs have increased values during the first half of the period and decline afterwards.

\section{LPAZ 4 (2.90 - $2.12 \mathrm{~m} ; 2400$ - 1770 cal. yr BP)}

Alnus and the wetland herbs values further increase. Carpinus betulus pollen percentages are slightly higher than recorded at the end of the previous zone. Towards the middle of the zone, Fagus sylvatica values gradually increase. The abrupt drop of $C$. betulus values is associated with a slight decline of the other deciduous trees as well (Quercus, Tilia, and Ulmus). For a short while afterwards, Carpinus betulus and Pinus percentage values increase at the expense of Fagus sylvatica. Vitis values increase and taxa indicators of grazing activities, such as Plantago lanceolata, Chenopodiaceae and Fabaceae, begin to diversify and expand. Sphagnum replaces most of the wetland herbs.

\section{LPAZ 5 (2.12-0.90 m; 1770 - 730 cal. yr BP)}

Alnus and Fagus sylvatica have high values at the beginning of the zone. An increase of Corylus avellana (from 5\% to 12\%) is noted at the expense of Carpinus betulus and Ulmus. Afterwards, the dominant taxa (Alnus and F. sylvatica) decline, while C. betulus percentage values increase. Thereafter, Alnus and Fagus sylvatica pollen percentages slowly increase and Carpinus betulus values (10\%) decline at the expense of Corylus avellana (20\%). For the rest of the zone, Fagus sylvatica has the dominant values, with Alnus glutinosa percentage values slightly decreasing. Carpinus betulus and Quercus regain increasing values. These mesothermophilous taxa are accompanied by warmth loving species such as Hedera and Viscum. A noticeable characteristic of the zone are the increasing NAP values, mainly influenced by the large amounts of hygrophilous Scrophulariaceae species (Gratiola officinalis and Limosella aquatica). The wetland Scrophulariaceae values reach their maximum (ca. 30\%), along with an additional increase of the Poaceae percentages. At this point, Sphagnum values drop markedly. Anthropogenic indicators diversify furthermore and some occur regularly (Cerealia, Solanaceae, Plantago lanceolata). Vitis pollen percentages are still regular during the Alnus glutinosa dominated part of the zone, but start to decrease and eventually become sparse as soon as the wetland Scrophulariaceae and other herbs' pollen percentages decrease. Juglans pollen occurs here for the first time in the sequence.

\section{LPAZ 6 (0.90 - 0 m; 730 cal. yr BP - present)}

In the first half of the zone, Fagus sylvatica reaches a maximum at 630 cal. yr BP, only to abruptly decrease (from $60 \%$ to $30 \%$ ) shortly after, at around 550 cal. yr BP, then reaching 50\% at 


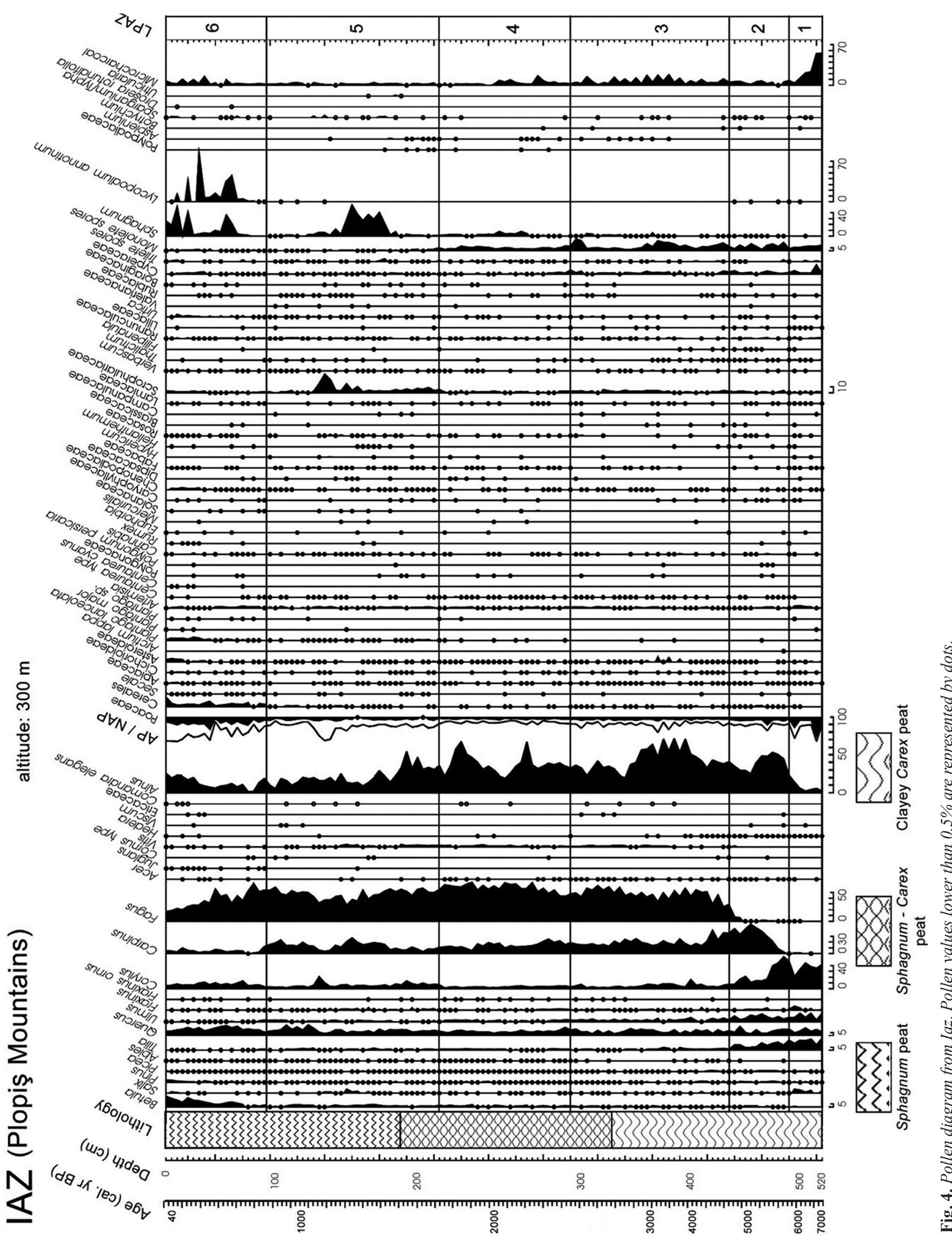


350 cal. yr BP. Carpinus betulus, Ulmus and Fraxinus decline rapidly and percentage values of Quercus and pioneer tree taxa such as Corylus avellana and Betula start to increase. The values of Fagus sylvatica and the other mesothermophilous trees begin to decline rapidly at the expense of Betula and Alnus. Pinus and Salix are other taxa with increasing values during this time. Juglans pollen has a regular presence in the second half of the zone. As far as the NAP is concerned, the main constituents are Poaceae and Cerealia along with a number of other human indicators (Asteroideae, Plantago lanceolata, Chenopodiaceae, Rumex, Urticaceae). Centaurea cyanus occurs for the first time in this zone and becomes regular during the last part, where microcharcoal values also increase. The end of the sequence shows an increase in wetland Scrophulariaceae, Cyperaceae and Typha. These changes in NAP values are also associated with an abrupt increase in Sphagnum and Lycopodium annotinum values, with the foremost maintaining high values towards the end of the zone.

\section{DISCUSSION}

\section{Vegetation history}

Our study on the Iaz peat sequence presents new results on vegetation dynamics in the sub-mountainous region of NW Romania, an understudied region. This pollen record can be correlated with the available data from other investigations in the northwest of Romania (Bodnariuc et al., 2002; Björkman et al., 2003; Jalut et al., 2003; Fărcaş et al., 2005; Feurdean et al., 2005, 2007, 2008, 2013; Feurdean and Willis, 2008) to give a general picture of the Holocene forest development in this submountainous region of South-Eastern Europe.

$7000-5450$ cal. yr BP $(5.20-4.75 \mathrm{~m})$

The transition from gyttja to a clayey peat at ca. $7000 \mathrm{cal}$. yr BP suggests the start of the development of the sequence as a peat bog.

The landscape surrounding it was dominated by wetland herbs like Cyperaceae and Poaceae and a few patches of Alnus trees. The surrounding forest was dominated by Corylus avellana, Tilia, Quercus and Ulmus.

Between 6700 and 6300 cal. yr BP the mesothermophilous forest belt was in very close proximity to the peat bog. Forests dominated by Corylus avellana along with Tilia, Quercus and Ulmus were present in the vicinity of the wet zone. The margins of the peat bog were colonized by Typha, Sparganium and ferns, as well as some shrubs such as Salix and Hedera. Carpinus betulus also started to be part of this forest. Similar vegetation dynamics can be found in the sequences from Preluca Țiganului (Feurdean, 2005), Turbuţa (Feurdean et al., 2007), Steregoiu (Björkman et al., 2003), Ic Ponor (Bodnariuc et al., 2002, Jalut et al., 2003).

Between 6300 and 5700 cal. yr BP, the outer forest belt of Corylus avellana and broadleaf trees declined, giving way to the rapid development of the Alnus glutinosa inner belt. Betula, Fraxinus and Salix were other taxa that inhabited the nearby wetland. The relatively higher concentration of Picea abies pollen suggests the descent of this taxon to lower elevations on the west and northwest slopes nearby the peat bog. These shifts in the vegetation suggest colder conditions which correlate with results concerning a low fire activity in the Lake Ştiucii sequence (Feurdean et al., 2013). Abies alba was recorded for the first time at ca. 5700 cal. yr BP. The rise in Alnus participation in the woodlands is also noted in the sequences from Preluca Ţiganului (Feurdean, 2005), Turbuţa (Feurdean et al., 2007), and Ic Ponor
(Bodnariuc et al., 2002, Jalut et al., 2013) and Căpăţâna (Fărcaş et al., 2005) during this period.

The margins of the Iaz peat bog expanded between 6300 and 5700 cal. yr BP once again, the most common taxa being Poaceae and ferns. Furthermore, the presence of herb taxa such as Apiaceae, Caryophyllaceae, Chenopodiaceae and Lycopodium indicate a slight acidification of the soil. During this period of time, the first occurrence of Cerealia and Secale pollen is also noted.

Between 5700 and 5450 cal. yr BP the outer belt dominated by Corylus avellana and other broadleaf trees expanded. Afterwards these taxa (Corylus avellana, Quercus, Tilia and Ulmus) gradually gave way to Carpinus betulus as the main component. Scarce Fagus sylvatica and Acer trees also inhabited the area. The tree belt adjacent to the peat bog was dominated by Alnus, whereas the margins were dominated by species of ferns and Scrophulariaceae. Some parts of the wet zone started to be colonized by Sphagnum species.

The land nearby the peat bog was auspicious for Artemisia, Arctium lappa, Chenopodiaceae, Centaurea sp. and Cerealia as well.

\section{$5450-4500$ cal. yr BP $(4.75-4.40 \mathrm{~m})$}

Carpinus betulus became dominant among the trees in the mesothermophilous belt surrounding the peat bog, slightly expanding towards the inner Alnus belt as well. Once Fagus sylvatica started expanding (ca. 4800 cal. yr BP), the participation of Carpinus betulus in the woodlands decreased. The increased Quercus contribution to the woodland composition suggests warmer conditions, as derived from Lake Ştiucii proxy record (Feurdean et al., 2013). The occurrence of Abies alba was in close relationship with the spreading of Fagus sylvatica. The forests from Preluca Ţiganului (Feurdean, 2005) and Molhaşu Mare (Feurdean and Willis, 2008) show a similar development regarding the mesothermophilous taxa (Quercus, Ulmus, Tilia) during this period of time, in spite of the earlier expansion of Fagus sylvatica (5000 cal. yr BP).

The conditions in the center of the Iaz peat bog were less humid, as patches of Sphagnum started to gradually overgrow the swamp. The banks were inhabited by wetland herbs (Cyperaceae, Valerianaceae, Filipendula, Thalictrum) and ferns.

The open land in the vicinity of the peat bog was mainly used for the cultivation of Cerealia and Vitis. Plantago lanceolata and Rumex colonized the meadows and acidophilic species, such as Lycopodium and Urtica, began to grow in the area.

\section{$4500-2400$ cal. yr BP $(4.40-2.65 \mathrm{~m})$}

This period is characterized by several fluctuations in the development of the forest belts surrounding the peat bog. Intervals when Alnus was the dominant tree, and herbs and wetland herbs were abundant (4000 - 3400 cal. yr BP, 2800 - 2400 cal. yr BP) imply an outward expansion of the hygrophilous forest belt and a widening of the inner swamp. The widened rims were colonized mainly by ferns, fact also indicated by the numerous intact sporangia found in the pollen slides. All these happened at the expense of Fagus sylvatica and the other mesothermophilous taxa (Quercus, Tilia, and Fraxinus).

Fagus sylvatica was the dominating tree during 4500 - 4000 cal. yr BP and 3400 - 2800 cal. yr BP. Its prevalence in the outer woodlands prevented the expansion of other broadleaf trees.

These shifts in vegetation can be correlated with the results from Preluca Ţiganului sequence between 4500 and 2400 cal. yr BP (Feurdean at al., 2008). Thus, the wetter periods can be associated 
with the intervals when Alnus glutinosa was the dominant tree and wetland herbs were abundant in the Iaz sequence. The warmer periods were associated with the dominance of Fagus sylvatica and a decrease in the wetland herbs from the Iaz sequence. These shifts in vegetation can also be associated with the succession of dry and wet conditions found in the study on the Lake Ştiucii sequence (Feurdean et al., 2013).

Asteroideae, Plantago lanceolata and Polygonum persicaria inhabited the open lands in the proximity of the peat bog.

\section{0-1600 cal. yr BP (2.65 - $1.95 \mathrm{~m})$}

Fagus sylvatica reached its dominance in the area and thus the outer mesothermophilous forest belt expanded, limiting the surface of the Alnus belt and favoring the colonization of the wet zone by Sphagnum. The various insect remains and fungal spores identified (Cercophora type, Kretzschmaria deusta), as well as the wood and vegetal remains found in the pollen slides, also indicate the extension of the forest on the peat bog surface, probably due to the prevalence of warm and dry conditions. The open terrains were colonized by Plantago lanceolata and Dipsacaceae.

Between 2000 and 1800 cal. yr BP, the forest adjacent to the peat bog also recovers and it is dominated by Alnus glutinosa. The mesothermophilous woodland expands and the moist conditions allow Fagus sylvatica to thrive. Subsequently (1800 - 1600 cal. yr BP), the center of the peat bog was colonized by different species of wetland Scrophulariaceae (Gratiola officinalis, Limosella aquatica), which prevented a further expansion of the Alnus glutinosa woodland.

The succession of warm and dry, and colder and humid conditions can be correlated with the results from Preluca Ţiganului (Feurdean et al., 2008), with a similar dynamic of the main taxa as in the Iaz area: Fagus sylvatica and Alnus glutinosa. The Lake Ştiucii sequence (Feurdean et al., 2013) suggests wetter conditions between 2200 and 1800 cal. yr BP and a higher probability of fire occurrence (dry conditions) between 2400 and 2200 cal. yr BP, and between 1800 and1600 cal. yr BP. The higher concentration of microcharcoal in the sequence from Molhaşu Mare (Feurdean and Willis, 2008) between 2400 and 1800 cal. yr BP also indicates a dry and fire-prone period of time in the area which is correlated well with our data from Iaz.

Plantago lanceolata and species of Asteroideae and Apiaceae are the main constituents of the nearby open land.

\section{$1600-1100$ cal. yr BP $(1.95-1.40 \mathrm{~m})$}

The inner Alnus belt reached half of the surface previously inhabited (Fig. 4). Carpinus betulus replaced Fagus sylvatica during the onset of the decline of the mesothermophilous trees at 1500 cal. yr BP. Betula and Salix have a slight increase in participation in the woodlands around the peat bog between 1500 and 1300 cal. yr BP, which, together with a slightly higher occurrence of Pinus, support the establishment of a cooler climate. Between 1300 and 1100 cal. yr BP Carpinus betulus is again replaced by Corylus avellana and Fagus sylvatica. The plants that colonized the center of the peat bog between 1600 and 1300 cal. yr BP were species of Sphagnum, followed by the occurrence of hygrophilous Scrophulariaceae species (Gratiola officinalis, Limosella aquatica) along with other wetland herbs (Valerianiaceae, Thalictrum, Epilobium, Typha and Sparganium, Utricularia and Rubiaceae) between 1300 and 1100 cal. yr BP

Based on the vegetation shifts, the climate was cold and dry between 1600 and 1300 cal. yr BP, and warmer with a possible flooding episode in the peat bog between 1300 and 1100 cal. yr BP. The deduced cold and dry climate conditions identified in our sequence, between 1600 and 1300 cal. yr BP, and the warmer conditions, between 1300 and 1100 cal. yr BP, can also be correlated with the results from Preluca Țiganului (Feurdean et al., 2008) and Lake Ştiucii (Feurdean et al., 2013). The vegetation shifts are similar to the ones in the sequence from Molhaşu Mare (Feurdean and Willis, 2008).

The land in the vicinity of the peat bog was colonized by Plantago lanceolata, Rumex, Helianthemum and species of Rosaceae.

\section{$1100-635$ cal. yr BP $(1.40-0.80 \mathrm{~m})$}

The mesothermophilous trees continued to recover and Fagus sylvatica was the prevailing tree in the outer woodland belt. However, Alnus glutinosa was not able to fully recover and the wet zone remained inhabited by Sphagnum species and ferns. Lycopodium annotinum started to colonize the wet zone as well.

The increasing participation of mesothermophilous trees in the woodlands can also be identified in the study of the Molhaşu Mare sequence (Feurdean and Willis, 2008). The study on the Lake Ştiucii sequence indicated a warm and dry period between 1000 and 700 cal. yr BP.

\section{5 cal. yr BP-present $(0.80-0 \mathrm{~m})$}

The mesothermophilous Fagus sylvatica dominated belt was decreasing, while pioneer trees like Betula and Pinus started to colonize the space in the forests. Cerealia, Secale, ruderal and pasture species (Poaceae, Plantago lanceolata, Fabaceae, Apiaceae, Chenopodiaceae, Centaurea cyanus) were abundant in the meadows nearby the peat bog, indicative of increasing human pressure on the surrounding forest..

In the last 200 years, Alnus and wetland herbs like Typha and Sparganium, Scrophulariaceae, Ranunculaceae and ferns began to repopulate the inner part of the peat bog. Sphagnum and Lycopodium annotinum colonized the wet zone, the former one dominating until present times.

\section{Human impact}

The lowlands adjacent to the Plopiş Mountains (NW Romania) have been proven to be contact areas between the Neolithic and Early Eneolithic human cultures from the Transylvanian Depression and the rest of the northwestern part of Romania. The archaeological findings have shown an almost continuous inhabitance of the area starting with the Starčevo-Criş III B complex (ca. 7600 - 7300 cal. yr BP). The main pursuits of the group were pottery, agriculture and animal breeding (Băcueț, 2008).

The human impact in the pollen diagrams from sites located in the Apuseni Mountains is more obvious during the Middle to Late Holocene (Fărcaş et al., 2003a, 2003b; Fărcaş and Tanţău, 2004; Feurdean and Willis, 2008; Geantă et al., 2012). The first signs of human presence in the Apuseni Mountains, as provided by ${ }^{14} \mathrm{C}$ dated pollen diagrams, go back as far as 7100 cal. yr BP (Bodnariuc et al., 2002; Jalut et al., 2003)

The first evidence of human activity in our sequence can be correlated with the first pollen record of Cerealia at around 6300 cal. yr BP. The open lands and areas near the Neolithic settlements were auspicious for Artemisia, Arctium lappa, Chenopodiaceae and Centaurea sp. Starting with ca. 4500 cal. yr BP, Vitis has a noticeable occurrence in the landscape especially between 2400 and 1500 cal. yr BP, which coincides with the Roman Warm period. 
Up until 635 cal. yr BP, the land nearby the peat bog was mainly colonized by grazing indicators, such as Artemisia, Plantago lanceolata and Poaceae. The pastoral activities are supported by the various coprophilous spores (Sordaria type, Cercophora type, Tricodelitschia type, Coniochaeta type, Apiosordaria type) identified in the pollen slides. There are also a few pollen grains of Cerealia, probably originating from cultivated land further from the meadows. The first occurrence of Juglans pollen is found at $1400 \mathrm{cal}$. yr BP.

Over the last 600 years, one can notice a continuous reduction in the proportion of Fagus sylvatica and Carpinus betulus, coincident with the establishment of Betula, Quercus and Corylus avellana forests. Forest clearance over the last 600 years, followed by colonization of Betula (in the inner forest belt) and $C$. avellana (in the outer forest belt) most probably led to the present forest composition. The main purpose of fires over the past 300 years was probably to manage pastoral and agricultural fields (Feurdean and Willis, 2008).

\section{CONCLUSIONS}

The peat sequence from Iaz provides a high-resolution record of the forest dynamics and human impact over the past 7000 years in the sub-mountainous region of NW Romania.

At the onset of the peat bog (ca. 7000 cal. yr BP) the local woodlands were dominated by Corylus avellana. The Alnus glutinosa forest belt surrounding the peat bog started to expand at ca. 5700 cal. yr BP. Although present in the outer thermophilous forest belt from around 6000 cal. yr BP, Carpinus betulus and Fagus sylvatica only expanded at 5700 and probably 4800 cal. yr BP, respectively.

Human impact in the area is recorded as far back as $6300 \mathrm{cal}$. yr BP. In spite of being present regularly throughout our entire sequence in a wide variety, the main human activity indicators are related to pastoral activities in the proximity of the peat bog up until 635 cal. yr BP. The last 600 years show a rise in deforestations and agricultural activities closer to the peat bog, which probably led to a significant change in the local vegetation.

Acknowledgement. The authors gratefully acknowledge support from the Romanian National Authority for Scientific Research, UEFISCDI, Project number PN-II-PTPCCA-2011-3.1-0924. Valuable suggestions on an early version of the manuscript from two anonymous reviewers and the editors are greatly appreciated.

\section{REFERENCES}

Băcueț-Crişan, S. 2008, Neolithic and Early Eneolithic from the Şimleu Depression. Brukenthal National Museum, Alba Iulia, 340 p. (in Romanian).

Björkman, S., Feurdean, A. \& Wohlfarth, B. 2003, Late glacial and Holocene forest dynamics at Steregoiu in the Gutâiului Mountains, Northwest Romania. Review of Palaeobotany and Palynology, 124: 79-111.

http://dx.doi.org/10.1016/S0034-6667(02)00249-X

Blaauw, M. 2010, Methods and code for 'classical' agemodelling of radiocarbon sequences. Quaternary Geochronology, 5: 512-518.

http://dx.doi.org/10.1016/j.quageo.2010.01.002
Bodnariuc, A., Bouchette, A., Dedoubat, J.J., Otto, T., Fontugne, G.J. \& Jalut G. 2002, Holocene vegetational history of the Apuseni Mountains, central Romania. Quaternary Science Reviews, 21: 1465-1488. http://dx.doi.org/10.1016/S0277-3791(01)00117-2

Coldea, G. 1971, The pollen diagram of the Băile Iaz peatbog (Plopiş Mountains). Studii şi Cercetări de Biologie (Botanică), 22: 17-22 (in Romanian).

Fărcaş, S., Lupşa, V., Tanţău, I. \& Bodnariuc, A. 2003a, The observation of the anthropization process in pollen diagrams from the Apuseni Mountains. Petrescu, I., (ed.) Environment \& Progress, Cluj-Napoca, 231-236.

Fărcaş, S., Tanţău, I. \& Bodnariuc, A. 2003b, The holocene human presence in Romanian Carpathians, revealed by the palynological analysis. Benedek, J., Schulz, E., "Sammelband Rumänien Ungarn, Würzburger Gepgraphische Manuskripte", Würzburg, 63: 113-130.

Fărcaş, S., Tanţău, I. 2004, The human presence in pollen diagrams from Romanian Carpathians. Anthaeus, Budapest, 27: 227-234.

Fărcaş, S., de Beaulieu, J.L., Tanţău, I. \& Stoica, I.A. 2005, The absolute chronology aspects of the postglacial vegetation registered in the Căpăţâna peat bog, Apuseni Mountains. Studii şi cercetări (Biologie), Bistriţa, 10: 99-108.

Fărcaş, S., Tanţău, I. \& Feurdean, A. 2007, L'histoire des forets et du paleoclimat holocene dans les Monts Apuseni. Contributiii Botanice, XLII, Cluj-Napoca, 1: 115-125.

Feurdean, A. 2005, Holocene forest dynamics in northwestern Romania. Holocene, 13: 435-446. http://dx.doi.org/10.1191/0959683605hl803rp

Feurdean, A., Mosbrugger, V., Onac, B.P., Polyak, V. \& Vereş, D. 2007, Younger Dryas to mid-Holocene environmental history of the lowlands of NW Transylvania, Romania. Quaternary Research, 68: 364-378. http://dx.doi.org/10.1016/j.yqres.2007.08.003

Feurdean, A., Willis, K.J. 2008, The usefulness of a longterm perspective in assessing current forest conservation management in the Apuseni Natural Park, Romania. Forest Ecology and Management, 256: 421-430.

http://dx.doi.org/10.1016/j.foreco.2008.04.050

Feurdean, A., Klotz, S., Mosbrugger, V. \& Wohlfarth, B. 2008, Pollen-based quantitative reconstructions of Holocene climate variability in NW Romania. Palaeogeography, Palaeoclimatology, Palaeoecology, 260: 494-504. http://dx.doi.org/10.1016/j.palaeo.2007.12.014

Feurdean, A., Liakka, J., Vanniere, B., Marinova, E., Hutchinson, S.M., Mossbruger, V. \& Hickler, T. 2013, 12,000-Years of fire regime drivers in the lowlands of Transylvania (CentralEastern Europe): a data-model approach. Quaternary Science Reviews, 81: 48-61. http://dx.doi.org/10.1016/j.quascirev.2013.09.014

Geantă, A., Tanţău, I., Tămaş, T. \& Johnston, E.V. 2012, Palaeoenvironmental information from the palynology of an 800 year old bat guano deposit from Măgurici cave, NW Romania (Romania). Review of Palaeobotany and Palynology, 174: 57-66. http://dx.doi.org/10.1016/j.revpalbo.2011.12.009

Goeury, C. 1997, GpalWin: gestion, traitement et représentation de la paléoécologie. In XV-ème Symposium de l'APLF (Association des Palynologues de Langue Française). Université Claude Bernard, Lyon, 31 p. 
Institute of Biological Research, Management Plan for the “Mlaștina de la Iaz” Natural Reservation, http://www.mmediu.ro/planmanagementmlastinadelaiaz.pdf Jalut, G., Bodnariuc, A., Bouchette, A., Dedoubat, J.J., Otto, T. \& Fontugne, M. 2003, Holocene vegetation and human impact in the Apuseni Mountains, Central Romania. Aspects of Palynology and Palaeoecology, (S. Tonkov, ed.), Pensoft Publ., 137-170.

Lazarovici, G. 1993, Les Carpates Méridionales et la Transylvanie. In: Kozlowski, J., Van Berg, P.L. (Eds.), Atlas du Néolithique européen. L'Europe orientale. Etudes et Recherches Archéologiques de l'Université de Liège, Marcel Ottepublisher, Liège, 243-284.

Mantu, C.M. 1998, The Absolute Chronology of the Romanian Neolithic and Aneolitic/Chalcolitic Periods. The State of Research. Mémoires de la Société Préhistorique Française, T. XXVI, 1999. Suppl. 1999 Revue d'Archéométrie, Actes du colloque “C14-Archéologie”, 6 avril 1998, 225-231.

Munteanu, D., Raus, D.M. 1984, Documentaţii pentru crearea unor rezervaţii naturale de interes naţional în judeţul Sălaj. Acta Musei Porolissensis, Zalău, 8: 300-314.

Pop, E. 1932, Contributions to the Quaternary vegetation history from Transylvania. Buletinul Grădinii Botanice şi al Muzeului Botanic de la Universitatea din Cluj, 12: 29-102 (in Romanian).
Pop, E. 1960, Peat bogs from Romania. Editura Academiei Republicii Populare Române: Bucharest, 511 p. (in Romanian).

Reille, M. 1995, Pollen et Spores d'Europe et d'Afrique du Nord. Supplément 1. Laboratoire de Botanique Historique et Palynologie, Marseille, 327 p.

Reille, M. 1998, Pollen et Spores d'Europe et d'Afrique du Nord. Supplément 2. Laboratoire de Botanique Historique et Palynologie, Marseille, $521 \mathrm{p}$.

Reille, M. 1999, Pollen et Spores d'Europe et d'Afrique $d u$ Nord (Seconde édition). Laboratoire de Botanique Historique et Palynologie, Marseille, 535 p.

Reimer, P.J., Bard, E., Bayliss, A., Beck, J.W., Blackwell, P.G., Bronk Ramsey, C., Buck, C.E., Cheng, H., Edwards, R.L., Friedrich, M., Grootes, P.M., Guilderson, T.P., Haflidason, H., Hajdas, I., Hatté, C., Heaton, T.J., Hoffmann, D.L., Hogg, A.G., Hughen, K.A., Kaiser, K.F., Kromer, B., Manning, S.W., Niu, M., Reimer, R.W., Richards, D.A., Scott, E.M., Southon, J.R., Staff, R.A., Turney, C.S.M. \& van der Plicht, J. 2013, IntCal13 and Marine13 radiocarbon age calibration curves 0-50,000 years cal BP. Radiocarbon, 55 (4): 1869-1887. http://dx.doi.org/10.2458/azu js rc.55.16947

Tutin, T.G., Heywood, V.H., Burgess, N.A. Valentine, D.H., Walters, S.M. \& Webb, D.A. 1964-1980, Flora Europaea, vol. 11964 (464 p), vol. 21968 (486 p), vol. 31972 (399 p), vol. 41976 (534 p), vol. 51980 (476 p). Cambridge University Press, Cambridge. 